\title{
Farewell to Caledonia
}

We begin and end this issue of our journal with articles on communication. The first explores changes technology will bring; the last presents a survey of publishing opportunities in library periodicals.

In their survey article Daniel O'Connor and Phyllis Van Orden present, for the first time, information on one's chances in getting an article published in some of our principal journals. They focus on the procedures editors follow in making that all-important decision to authors: to publish or not to publish.

While O'Connor and Van Orden call our attention to the hurdles authors face as they seek publication, F. Wilfrid Lancaster in his opening article takes us beyond this day of print on paper in looking toward the paperless society. Instead of journal articles nearly arranged in bound volumes on library shelves, these contributions will be stored in a computer and called up on demand through a terminal in the library, or even in the reader's home.

Although the technology described may seem a long way from the print-and-paper-limited library society of today, Lancaster does point out how reviewing and refereeing of potential contributions will continue much in the same way that some journals practice today. With the on-line editing and refereeing capabilities he describes, our contributions will surely improve.

Thus as we look to the beginning of this paperless society with its electronic journals, those of us raised in the tradition of such friends as Baskerville and Times Roman will say goodbye to them and what their presence and arrangement on paper have meant to us. And here at $C \& R L$ we may even bid our own farewell to Caledonia.

R.D.J. 


\section{NEW Up-To-Date Books From Noyes Data}

NOYES DATA has developed two new techniques of vital importance to those who wish to keep abreast of rapid changes in technology and business conditions: 1 ) our advanced publishing systems permit us to produce durably-bound books within a few months of manuscript acceptance; 2) our modern processing plant ships all orders on the day after they are received.

\section{HARDCOVER BOOKS-FALL 1978}

ELECTROPLATING AND RELATED METAL FINISHING-POLLUTANT AND TOXIC MATERIALS CONTROL by M. Sittig: Since simple dilution of the pollutants is no longer acceptable this book presents methods for advanced treatment and detoxification of fumes and wastewaters with excellent recovery of metal values. Ways toward development of a zero discharge technology are also shown. ISBN 0-81550716-X; $\$ 48$

UNIT OPERATIONS FOR TREATMENT OF HAZARDOUS INDUSTRIAL WASTES edited by D.J. De Renzo: There exists an urgent and immediate need for treatment processes which can detoxify, destroy or apply recovery principles to industrial wastes. This study examines over $\mathbf{4 0}$ basic unit engineering processes for their applicability to treating hazardous wastes. ISBN 0-8155-0717-8; $\$ 42$

DAIRY PRODUCTS AND EGGS-RECENT DEVELOPMENTS by M. Gutcho: This book is intended for food technologists and food processors, with heavy emphasis on facilitating processing, increasing yields, shortening ripening time, lengthening shelf life, and improving flavor. ISBN 0-8155-0718-6; \$39

METHANOL TECHNOLOGY AND APPLICATION IN MOTOR FUELS edited by J.K. Paul: This book contains detailed descriptive information relating to methanol production from unusual and renewable sources, the utilization of methanol as an automotive fuel, and the conversion of methanol into gasoline. ISBN 0-8155-0719-4; \$54

PAINT ADDITIVES-RECENT DEVELOPMENTS by G.B. Rothenberg: Various additives incorporated into organic coatings, usually in small quantities, give specific properties to a paint formulation that are quite important to the ultimate user. Through the proper use of these additives, as shown in this book, the paint technologist can usually formulate a higher quality paint at little increase in cost. ISBN 0-8155-0720-8; \$36

FERTILIZER ADDITIVES AND SOIL CONDITIONERS by M.W. Ranney: This book describes close to 200 processes related to the improvement of fertilizers and soil conditioners through the use of minor, but essential, additives which utilize nutrient values, commonly available at low cost, but hitherto considered as useless by-products and waste. ISBN 0-8155-0721-6; \$39

COAL ASH UTILIZATION-FLY ASH, BOTTOM ASH AND SLAG edited by S. Torrey: Energy and environmental considerations point to a greater use of coal. This book shows how millions of tons of fly ash and other ashes can be disposed of annually in an environmentally acceptable manner, e.g. as lime + fly ash aggregates together with cement for pavements, buildings and bridges, etc. ISBN 0-8155-0722-4; \$39 